\title{
Glucagon-like peptide-2 (GLP-2) increases small intestinal blood flow and mucosal growth in ruminating calves
}

\author{
C. C. Taylor-Edwards, ${ }^{\star 1}$ D. G. Burrin, $†$ J. J. Holst $\neq \neq$ K. R. McLeod, ${ }^{\star}$ and D. L. Harmon ${ }^{\star 2}$ \\ *Department of Animal and Food Sciences, University of Kentucky, Lexington 40546 \\ TUSDA/ARS Children's Nutrition Research Center, Baylor College of Medicine, Houston, TX 77030 \\ ‡Department of Biomedical Sciences, The Panum Institute, University of Copenhagen, Denmark
}

\section{ABSTRACT}

Glucagon-like peptide-2 (GLP-2) increases small intestinal mass and blood flow in nonruminants but its effect in ruminants is unknown. Eight Holstein calves with an ultrasonic flow probe around the superior mesenteric artery and catheters in the carotid artery and mesenteric vein were paired by age and randomly assigned to treatment of a control $(0.5 \%$ of BSA in saline; $\mathrm{n}=4)$ or GLP-2 $(50 \mu \mathrm{g} / \mathrm{kg}$ of body weight of bovine GLP-2 in BSA; $\mathrm{n}=4$ ) given subcutaneously every $12 \mathrm{~h}$ for $10 \mathrm{~d}$. Blood flow was measured on d 0 (acute) and d 10 (chronic) and included 3 periods: baseline (saline infusion), treatment (infusion of BSA or 1,000 pmol of GLP- $2 / \mathrm{kg}$ of body weight per $\mathrm{h}$ ), and recovery (saline infusion). On d 11, calves were killed $2 \mathrm{~h}$ after injection of 5-bromo-2'-deoxyuridine (BrdU). Gastrointestinal tissues were weighed and epithelial samples were obtained to determine villus height, crypt depth, and BrdU staining. Infusion of GLP-2 increased superior mesenteric artery blood flow to $175 \%$ of baseline on $\mathrm{d}$ 0 but to only $137 \%$ of baseline after chronic treatment. Compared with that of the control, GLP-2 increased small intestinal mass by $24 \%$ by increasing epithelial mass in the jejunum and ileum. Additionally, GLP-2 increased villus height, crypt depth, and BrdU-labeling in small intestinal segments. These results demonstrate that GLP-2 induces similar increases in small intestinal blood flow and growth in ruminants to those observed in nonruminants. Furthermore, GLP-2 increases small intestinal blood flow in ruminants but this response is attenuated after $10 \mathrm{~d}$ of GLP-2 administration. In cattle, GLP-2 may be an important hormone in the regulation of intestinal blood flow and epithelial growth.

Key words: glucagon-like peptide-2, small intestine, blood flow, calf

\section{INTRODUCTION}

Ruminants have a uniquely complex gastrointestinal tract that undergoes substantial changes during the

Received June 16, 2010.

Accepted October 3, 2010.

${ }^{1}$ Current address: Center for Veterinary Medicine, US Food and Drug Administration, Rockville, MD.

${ }^{2}$ Corresponding author: dharmon@uky.edu animal's lifetime. The most dramatic of these changes occurs following weaning, but growth of the ruminant gastrointestinal tract also occurs upon initiation of lactation, as one necessary adaptation of maternal tissues to meet metabolic demands of the periparturient animal is hypertrophy of the gastrointestinal tract (Bauman and Currie, 1980) and is likely concurrent with increased feed intake during early lactation (Ingvartsen and Andersen, 2000; Reynolds et al., 2004). Indeed, the trophic effect of increased feed intake on gastrointestinal mass in ruminants is well documented (Johnson et al., 1990; McLeod and Baldwin, 2000).

Glucagon-like peptide-2 (GLP-2) is a 33 -amino acid hormone secreted by the enteroendocrine L-cell within the gastrointestinal tract in response to luminal nutrients (Massimino et al., 1998). The hallmark of GLP-2 action is an increase in small intestinal mucosal growth (Drucker et al., 1996;; Tsai et al., 1997a,b). In pigs and rodents, this stimulation of small intestinal growth is evidenced by increased villus height and crypt depth (Burrin et al., 2000; Hartmann et al., 2000b; Ramsanahie et al., 2004), which is mediated by greater crypt cell proliferation (Drucker et al., 1996; Tsai et al., 1997a; Burrin et al., 2005) and reduced villus cell apoptosis (Tsai et al., 1997a; Burrin et al., 2000, 2005). A second established action of GLP-2, observed in pigs, rats, and humans, is a rapid increase in blood flow, specifically of vessels supplying and draining the small intestine, such as the superior mesenteric artery (SMA) and portal vein (Guan et al., 2003, 2006; Stephens et al., 2006; Deniz et al., 2007; Bremholm et al., 2009). However, the effect of GLP-2 on blood flow has only been investigated in experiments utilizing short-term infusions $(<4$ h) of GLP-2 and, thus, no experiments have evaluated the blood flow response to GLP-2 after extended GLP2 administration. Moreover, in vitro desensitization of the GLP-2 receptor in response to high GLP-2 concentrations has been observed (Walsh et al., 2003; Estall et al., 2004). If this phenomenon also occurred in vivo, the responsiveness of blood flow to GLP-2 after long-term administration could be altered.

The majority of the existing published research described above investigating the effects of GLP-2 on intestinal growth and blood flow was conducted in 
nonruminant animals (rodents, pigs, humans), yet the biological function of GLP-2 in ruminants is unknown. However, we recently showed that cattle express mRNA encoding both proglucagon (the GLP-2 precursor) and the GLP-2 receptor in all segments of the gastrointestinal tract, with the highest expression occurring in the small intestine (Taylor-Edwards et al., 2010). Moreover, increasing dietary energy intake increased ileal proglucagon mRNA expression and plasma concentrations of active GLP-2 in cattle (Taylor-Edwards et al., 2010). Because GLP-1 and GLP-2 are co-secreted from the L-cell (Ørskov et al., 1986), changes in GLP-2 secretion can be inferred from changes in GLP-1 secretion. In dairy cows, plasma GLP-1 concentrations increased by $69 \%$ from $11 \mathrm{~d}$ precalving to $5 \mathrm{~d}$ postcalving, and linearly increased in the $19 \mathrm{~d}$ following calving (Relling and Reynolds, 2007b). Moreover, in cattle, plasma GLP-1 concentrations increased in parallel with food intake (Suominen et al., 1998; Relling and Reynolds, 2007b), and with infusions of lipid or casein into the abomasum (Relling and Reynolds, 2007a, 2008). These changes in secretion patterns are similar to those observed in nonruminants (Xiao et al., 1999; Raben et al., 2003), and suggest that the secretion of glucagonlike peptides is similar between ruminants and nonruminants. Thus, GLP-2 may provide a mechanism to mediate small intestinal mucosal growth in response to increased nutrient intake in the ruminant.

Therefore, the objectives of this experiment were to examine the effects of exogenously administered GLP2 on SMA blood flow and gastrointestinal mass and morphology changes in the ruminant. We hypothesized that GLP-2 would increase small intestinal mass by increasing the villus height and crypt depth of the proximal intestine compared with that of control calves. Additionally, the blood flow response to GLP-2 was investigated at the beginning and end of the experiment to evaluate the response of SMA blood flow to a 1-h intravenous GLP-2 infusion before and after $10 \mathrm{~d}$ of GLP-2 administration. We hypothesized that GLP-2 infusion would increase blood flow of the SMA in calves treated with GLP-2 but that this blood flow response would be diminished after $10 \mathrm{~d}$ of exogenous GLP-2 administration.

\section{MATERIALS AND METHODS}

\section{Animals and Surgical Procedures}

All experimental procedures were approved by the University of Kentucky Institutional Animal Care and Use Committee. Eight Holstein calves ( $41 \pm 3$ d of age) were obtained from the University of Kentucky dairy for use in this experiment. Calves were fed milk replacer twice daily with water and calf starter $[35.1 \%$ crimped oats, $30.1 \%$ cracked corn, $23.9 \%$ soybean meal, $7.6 \%$ molasses, vitamin and mineral premixes, and monensin $(6.6 \mathrm{~g} / \mathrm{kg})$ for coccidiosis prevention] available ad libitum before weaning ( $50 \pm 3 \mathrm{~d}$ of age). Following weaning, the diet was gradually adjusted to a 50:50 (wt/ wt) mixture of alfalfa cubes and calf starter. Dietary supplies of energy (1.64 MCal of $\mathrm{NE}_{\mathrm{M}} / \mathrm{kg}$ ), protein $(19.9 \%$ CP), vitamins, and minerals were adequate to meet normal growth requirements (National Research Council, 2001). Calves were fed this diet at $2.75 \%$ of BW before and throughout the experiment; their daily allotment was fed in 2 equally sized meals at 0730 and $1730 \mathrm{~h}$.

When calves were $97 \pm 7 \mathrm{~d}$ of age they were surgically prepared with a 4-mm ultrasonic flow probe (4R; Transonic Systems, Ithaca, NY) around the SMA along the distal duodenum. The criteria for probe placement included a repeatable location and an area with predominant arterial supply to the small intestine. The arterial supply to the proximal small intestine was located and the probe was placed as proximal as possible to any arterial branches to represent the maximally achievable arterial supply. Additionally, permanent indwelling catheters were inserted in a carotid artery and mesenteric vein by procedures adapted from Katz and Bergman (1969) and Huntington et al. (1989) as described by McLeod et al. (1997). Catheters were prepared as described by Huntington et al. (1989). Catheters and flow probe cable were tunneled subcutaneously and exteriorized along the spine at approximately the 5 th thoracic vertebrae. Before surgery, feed and water were withheld for 24 and $12 \mathrm{~h}$, respectively. On the day of surgery, calves were induced with xylazine (0.09 $\mathrm{mg} / \mathrm{kg})$ and ketamine $(1.8 \mathrm{mg} / \mathrm{kg})$, intubated, and maintained with isoflurane-oxygen (2 to $5 \%$ isoflurane) for the duration of the surgery. Prior to surgery calves were injected with the long-acting antibiotic ceftiofur (Excede, $6.6 \mathrm{mg} / \mathrm{kg}$ of BW, Pfizer Animal Health, New York, NY) and were administered flunixin meglumine (Flunixamine, $1.1 \mathrm{mg} / \mathrm{kg}$ of BW, Fort Dodge Animal Health, Fort Dodge, IA), with additional flunixin meglumine administered following surgery as needed for analgesia. Catheter exteriorization sites and suture sites were treated daily with antimicrobial ointment. Catheter patency was maintained by twice-weekly flushing and filling the catheters with a solution of gentamicin sulfate $(20 \mathrm{mg} / \mathrm{mL})$ and chymotrypsin $(225 \mathrm{U} / \mathrm{mL})$. Experimental procedures began approximately $16 \mathrm{~d}$ after surgery, once animals had maintained presurgery, ad libitum levels of feed intake for a minimum of $5 \mathrm{~d}$. At the beginning of the experiment calves weighed $126 \pm$ 
$7.7 \mathrm{~kg}$, were approximately $113 \pm 10 \mathrm{~d}$ of age, and had been weaned for over $60 \mathrm{~d}$, demonstrating that these were functional ruminants.

\section{Experimental Design}

Calves were paired by age before being assigned randomly to treatment, control $(\mathrm{n}=4)$ or GLP-2 $(\mathrm{n}=4)$. Only 2 calves (one per treatment) began experimental periods at any one time. Experimental periods were 11 $\mathrm{d}$ in length. On d 1 (acute), blood flow was measured as described below. After the blood flow measurements, calves were given their first dose of treatment via subcutaneous injection; injections were either vehicle $(0.5 \%$ BSA in saline, control) or GLP-2 (50 $\mu \mathrm{g}$ of GLP-2 $/ \mathrm{kg}$ of BW in vehicle, GLP-2). The GLP-2 used for both daily injections and the blood-flow experiment was synthesized (California Peptide Research, Inc., Napa, CA) based on the native bovine GLP-2 sequence (Lopez et al., 1983; Burrin et al., 2003). Treatments were administered by subcutaneous injection twice daily (every 12 h) for $10 \mathrm{~d}$. On d 10 (chronic), blood flow was again measured as described below. Calves were killed on $\mathrm{d}$ 11, approximately $2 \mathrm{~h}$ after an intravenous injection of 5-bromo-2'-deoxyuridine (BrdU), as described below.

\section{Blood Flow Measurements}

On d 1 and 10 of the experiment, blood flow was monitored for $2.5 \mathrm{~h}$ using the chronically implanted probe to measure SMA blood flow. Blood flow measurements were conducted after withholding the morning feeding to minimize prandial blood flow changes; thus, animals were fasted for approximately $12 \mathrm{~h}$ before the experiment. The blood-flow experiment consisted of 3 periods: 1) baseline infusion $\left(\mathbf{B}_{1}\right.$ or $\mathbf{B}_{10}$ for baseline on $\mathrm{d} 1$ or 10 , respectively) to establish baseline blood flow during a 30-min infusion of physiological saline, 2) treatment challenge infusion $\left(\mathbf{C}_{1}\right.$ or $\left.\mathbf{C}_{10}\right)$ in which calves were infused intravenously with their assigned treatment, either control or GLP-2 (1,000 pmol/kg per h) for $60 \mathrm{~min}$, and 3) saline infusion $\left(\mathbf{S}_{\mathbf{1}}\right.$ or $\left.\mathbf{S}_{\mathbf{1 0}}\right)$ in which calves were infused with physiological saline for $60 \mathrm{~min}$ to observe the recovery of blood flow after treatment challenge infusion. On d 10, the blood-flow experiment was started 3 to $7 \mathrm{~h}$ after the subcutaneous injection of treatment for that morning. Solutions were infused into the mesenteric vein catheter at a rate of $0.70 \mathrm{~mL} /$ min with a syringe pump (Harvard Apparatus model 22, Holliston, MA).

During all 3 infusion periods, real-time transit blood flow of the intestinal mesenteric artery was recorded by attaching the implanted blood flow probe to a blood flow meter (T106, Transonic Systems, Ithaca, NY) and data acquisition package (Windaq 194 datalogger and Data Acquisition System, Dataq Instruments, Akron, $\mathrm{OH})$. Arterial blood samples $(5 \mathrm{~mL}$ each) were taken every 15 min during the entire 2.5 -h recording period. This sampling frequency was chosen to ensure that several points would be obtained for any infusion period (B, C, or S). Blood samples were drawn into a chilled syringe containing sodium EDTA (final concentration $10 \mathrm{mg} \mathrm{EDTA} / \mathrm{mL}$ of blood). An aliquot of blood was transferred to a chilled tube containing aprotinin (to obtain a final concentration of 500 kallikrein inhibitory equivalents $/ \mathrm{mL}$ of blood), centrifuged at 10,000 $\times \mathrm{g}$ for $10 \mathrm{~min}$, and plasma stored at $-20^{\circ} \mathrm{C}$ for analysis of plasma GLP-2.

\section{Analysis of Plasma GLP-2 Concentrations}

Plasma preserved with aprotinin $(300 \mu \mathrm{L})$ was extracted with $70 \%$ ethanol (vol/vol, final concentration). Concentrations of GLP-2 in ethanol-extracted plasma were measured using a radioimmunoassay employing antiserum code no. 92160 (developed as described in Wojdemann et al., 1998) and standards of human GLP-2 (proglucagon 126-158, a gift from Novo Nordisk A/S) and monoiodinated Tyr GLP-2 (Ørskov and Holst, 1987), with a specific activity $>70 \mathrm{MBq} / \mathrm{nmol}$ (Hartmann et al., 2000a). The antiserum was directed against the $\mathrm{N}$ terminus of GLP-2 and, therefore, measured only fully processed GLP-2 of intestinal origin. A single assay was employed for all samples; sensitivity was $2 \mathrm{pmol} / \mathrm{L}$ and intraassay coefficient of variation was below $6 \%$.

\section{Tissue Harvest}

Calves were fasted for approximately $12 \mathrm{~h}$ before tissue harvest. On d 11, approximately $2 \mathrm{~h}$ after an intravenous injection of $10 \mathrm{mg}$ of $\mathrm{BrdU} / \mathrm{kg}$ of BW (Sigma Aldrich, St. Louis, MO), calves were killed using an overdose of barbituate and immediately eviscerated to obtain forestomachs (reticulorumen, omasum, and abomasum) and intestines (duodenum, jejunum, ileum, and colon). Forestomachs were separated from intestines and were stripped of all connective and adipose tissues.

Reticulorumen, omasum, and abomasum were separated and emptied of digestive contents. Tissue samples from the rumen, omasum, and abomasum were obtained from the cranial ventral sac, the large order I and II omasal plies, and the antral region, respectively. All forestomach samples were rinsed extensively with ice-cold saline before preserving for morphometric and immunohistochemical analyses by placing representative samples $\left(2.5 \times 2.0 \mathrm{~cm}^{2}\right)$ in cassettes and immersing 
in $10 \%$ phosphate-buffered formalin (Fisher Scientific SF 100-4, Pittsburgh, PA) for $48 \mathrm{~h}$ before transferring to $70 \%$ ethanol. Epithelial tissue was dissected away from tissue samples using scissors or scraping with a glass slide, and aliquots of epithelial tissue $(500 \mathrm{mg})$ were snap frozen in foil packs in liquid $\mathrm{N}$ before storage at $-80^{\circ} \mathrm{C}$ for DNA and protein analyses.

Small and large intestines and cecum were separated from the mesentery, divided, and lengths determined by looping the intestine across a wet stationary board, fitted with pegs at $2-\mathrm{m}$ increments, without tension to minimize stretching. Based on the total measured length, the small intestine was divided at the midpoint into proximal and distal sections. One-meter intestinal sections were excised from the duodenum $(0.5-1.5 \mathrm{~m}$ distal to the pyloric sphincter), jejunum ( $0.5 \mathrm{~m}$ to either side of the midpoint of the proximal small intestine), and ileum ( $0.5 \mathrm{~m}$ to either side of the midpoint of the distal small intestine). A 1-m section of colon (0.5 to $1.5 \mathrm{~m}$ distal of the ileocecal junction) was excised from the large intestine. Excised sections were immediately cut into two 0.5-m segments, gently stripped of digesta, cut longitudinally, and rinsed extensively with ice-cold physiological saline. Representative samples $(2.5 \times 2.0$ $\mathrm{cm}^{2}$ ) were removed from one $0.5-\mathrm{m}$ section and placed in $10 \%$ phosphate-buffered formalin for morphometric and immunohistochemical analyses as described for forestomach tissue samples. Epithelial tissue was harvested from the other $0.5-\mathrm{m}$ section by scraping with a glass slide over an ice-cold tray. All epithelial tissues and fat were removed from the $0.5-\mathrm{m}$ section and components (epithelial, fat, and nonepithelial tissue) were weighed to determine the proportions of epithelial and nonepithelial tissues. Aliquots of epithelial tissue (500 $\mathrm{mg}$ ) were snap frozen in foil packs in liquid $\mathrm{N}$ before storage at $-80^{\circ} \mathrm{C}$ for DNA and protein analyses.

After sample removal, remaining forestomachs (reticulorumen, omasum, and abomasum), intestines (small and large), cecum, and liver were rinsed with warm tap water to remove any digesta or debris, allowed to drip dry, and weighed. To obtain whole organ weights, weights of sampled sections and remaining organ were added together. Weights of all other components (adipose, connective tissue, hide, remaining organs, and carcass) were obtained to calculate whole body weight.

\section{Morphometry}

Formalin-fixed tissue pieces $\left(2.5 \times 2.0 \mathrm{~cm}^{2}\right)$ were dehydrated and embedded in paraffin. Blocks were sectioned (5- $\mu \mathrm{m}$ thick), mounted with each slide containing 2 to 3 sections, and stained with hematoxylin and eosin. Mean villus height and crypt depth were evaluated in at least 15 well-oriented crypt-villus units using an Axiophot microscope (Carl Zeiss Inc., Werk Göttingen, Germany) and Scion Image software (Scion Corporation, Frederick, MD).

\section{Immunohistochemistry}

Formalin-fixed, paraffin-embedded sections (5- $\mu \mathrm{m}$ thick) were incubated at $70^{\circ} \mathrm{C}$ for $10 \mathrm{~min}$, rehydrated with distilled deionized water, rinsed with PBS, and incubated in $1 \times$ target unmasking fluid (Invitrogen, Carlsbad, CA) at $90^{\circ} \mathrm{C}$ for $10 \mathrm{~min}$. The slides were incubated with $10 \%$ goat serum (Jackson ImmunoResearch Laboratories, West Grove, PA) at $40^{\circ} \mathrm{C}$ for 15 min, followed by a 45-min incubation of the slides with BrdU antibody/nuclease reagent (mouse monoclonal antibody clone \# BU-1, RPN202, GE Healthcare, Piscataway, NJ) at $40^{\circ} \mathrm{C}$. Slides were rinsed with PBS to remove excess primary antibody and incubated with PBS containing $0.3 \% \mathrm{H}_{2} \mathrm{O}_{2}$ and $0.1 \% \mathrm{NaN}_{3}$ for $10 \mathrm{~min}$ at room temperature followed by a 40-min incubation of the slides with biotinylated universal secondary antibody (goat anti-mouse $\operatorname{IgG}_{2 \mathrm{a}}$, sc-2073, Santa Cruz Biotechnology, Santa Cruz, CA) at $40^{\circ} \mathrm{C}$. Cells were incubated in avidin-biotin horseradish peroxidase complex (Vectastain ABC Kit, PK-4000, Vector Laboratories Inc., Burlingame, CA) and were visualized using 3,3'-diaminobenzidine (DAB Substrate Kit for peroxidase, SK-4100, Vector Laboratories Inc.). Slides were counter-stained with $0.1 \%$ hematoxylin solution for $35 \mathrm{~s}$ and dehydrated through an increasing series of ethanol and xylene solutions. The proportion of proliferating crypt cells was quantified by counting the number of BrdU-labeled nuclei in 20 vertically welloriented crypts and expressing this as a percentage of total nuclei per crypt.

\section{DNA and Protein Analyses of Epithelial Tissue}

Epithelial tissue (approximately $200 \mathrm{mg}$ ) was homogenized in $4 \mathrm{~mL}$ of water for $1 \mathrm{~min}$ and aliquots of homogenate were used for DNA or protein analysis. Analysis of DNA was conducted using bis-benzimide (Labarca and Paigen, 1980). Protein analysis was conducted using the bicinchoninic acid protein assay (Pierce, Rockford, IL) and a standard curve generated from BSA.

\section{Statistical Analysis}

The statistical model for analyzing gastrointestinal organ mass, morphometric measurements, and BrdU proliferative index included treatment as a fixed effect and block by treatment as random effects. The area under the curve (AUC) for SMA blood flow versus 


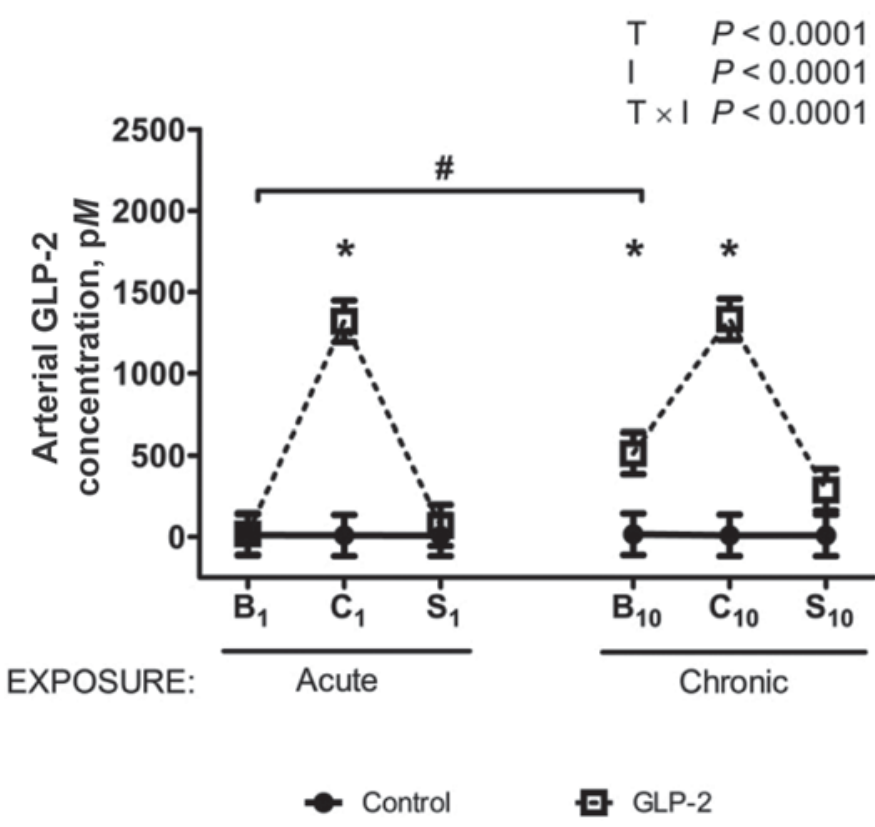

Figure 1. Arterial concentrations of active glucagon-like peptide-2 (GLP-2) in calves treated with a control $(\mathbf{\bullet} \mathrm{n}=4)$ or GLP-2 $(\square ; \mathrm{n}$ $=4)$. Response to baseline, treatment challenge, or saline infusion in calves not previously exposed to treatment (Acute; $\mathrm{B}_{1}, \mathrm{C}_{1}$, and $\mathrm{S}_{1}$ ) or after $10 \mathrm{~d}$ of treatment exposure (Chronic; $\mathrm{B}_{10}, \mathrm{C}_{10}$, and $\mathrm{S}_{10}$ ) was evaluated. Calves in the control group were given the vehicle $(0.5 \% \mathrm{BSA}$ in saline) during both the treatment challenge infusion periods $\left(C_{1}\right.$ and $\mathrm{C}_{10}$ ), and as a twice-daily subcutaneous injection for $10 \mathrm{~d}$. Calves in the GLP-2 treatment group were given 1,000 pmol of GLP-2/kg of BW per hour during the treatment challenge infusion periods $\left(\mathrm{C}_{1}\right.$ and $\left.\mathrm{C}_{10}\right)$, and $100 \mu \mathrm{g}$ of GLP-2/kg of BW per day as a twice-daily subcutaneous injection for $10 \mathrm{~d}$. Values are expressed as $\mathrm{p} M$ (means $\pm \mathrm{SE}$ ). Fixedeffect $P$-values for treatment (T; control or GLP-2), infusion period (I; $\mathrm{B}_{1}, \mathrm{C}_{1}, \mathrm{~S}_{1}, \mathrm{~B}_{10}, \mathrm{C}_{10}$, or $\left.\mathrm{S}_{10}\right)$, and their interaction are shown. Significant differences between $\mathrm{T}$ (control vs. GLP-2) within I are denoted by * $(P<0.05)$. Within GLP-2 treatment, significant differences between baseline $\left(\mathrm{B}_{1}\right.$ vs. $\left.\mathrm{B}_{10}\right)$, treatment challenge $\left(\mathrm{C}_{1}\right.$ vs. $\left.\mathrm{C}_{10}\right)$, or saline $\left(\mathrm{S}_{1}\right.$ vs. $\left.\mathrm{S}_{10}\right)$ infusions are denoted by \# $(P<0.05)$.

time was calculated using GraphPad Prism (version 5.00; GraphPad Software, San Diego, CA). The statistical model for analyzing SMA baseline blood flow and AUC included treatment ( $\mathbf{T}$; control or GLP-2), day (D; acute or chronic), and their interaction as fixed effects and block as a random effect. The statistical model for analyzing plasma GLP-2 concentrations and SMA blood flow included treatment $(\mathrm{T}$; control or GLP-2), infusion ( $\mathbf{I} ; \mathrm{B}_{1}, \mathrm{C}_{1}, \mathrm{~S}_{1}, \mathrm{~B}_{10}, \mathrm{C}_{10}$, and $\mathrm{S}_{10}$ ), and their interaction as fixed effects and block as a random effect. For blood flow variables, infusion was included as a repeated measure with the subject as calf (treatment). Multiple $t$-tests were used to compare the effect of treatment within each infusion and to compare the differences between baseline $\left(\mathrm{B}_{1}\right.$ vs. $\left.\mathrm{B}_{10}\right)$, treatment challenge $\left(\mathrm{C}_{1}\right.$ vs. $\left.\mathrm{C}_{10}\right)$, or saline $\left(\mathrm{S}_{1}\right.$ vs. $\left.\mathrm{S}_{10}\right)$ infusions within the GLP-2 treatment. A Bonferroni correction was used to correct $P$-values for multiple comparisons.
Blood flow for one calf in the GLP-2 treatment group was not measured because of blood flow probe failure; therefore, for SMA blood flow data, $\mathrm{n}=4$ for the control treatment group and $n=3$ for the GLP-2 treatment group. Results are expressed as mean \pm standard error, and significance for treatment effects and correlations was declared at $P<0.05$.

\section{RESULTS}

\section{GLP-2}

Plasma active GLP-2 concentrations are shown in Figure 1. As expected, GLP-2-treated calves had greater $(\mathrm{T} \times \mathrm{I}, P<0.0001)$ arterial concentrations of active GLP-2 during the treatment infusion periods than those treated with the control. In addition, chronic treatment with GLP-2 increased arterial GLP2 concentrations during the baseline infusion period compared with those from the control-treated calves ( $\mathrm{T}$ $\times \mathrm{I}, P<0.0001 ;$ Figure 1).

\section{Gastrointestinal Organ Mass and Intestinal Morphology}

After $10 \mathrm{~d}$ of treatment, neither live BW nor empty BW was affected by GLP-2 (Table 1). Treatment with GLP-2 for $10 \mathrm{~d}$ did not affect total gastrointestinal tract mass or mass of individual gastrointestinal organs, except the small intestine; GLP-2 increased $(P=0.03)$ small intestinal mass by $17 \%$ (data not shown). When expressed on an empty-BW basis (Table 1), GLP-2 increased $(P=0.04)$ small intestinal mass by $24 \%$ and tended $(P=0.09)$ to decrease abomasal mass, but did not affect mass of other individual gastrointestinal organs. Lengths of the small and large intestines and length:empty BW were not affected by treatment. Treatment with GLP-2 increased $(P=0.02)$ mass:length $(\mathrm{g} / \mathrm{m})$ of the small intestine but not the large intestine.

In the duodenum, GLP-2 did not affect mass of a $0.5-\mathrm{m}$ section (Table 2$)$. However, GLP-2 tended $(P=$ $0.10)$ to increase DNA and increased $(P=0.03)$ protein content of $0.5-\mathrm{m}$ duodenal sections. In the jejunum, GLP-2 increased $(P=0.009)$ total section mass by increasing $(P=0.008)$ epithelium mass and not affecting smooth muscle mass. Treatment with GLP-2 increased $(P=0.01)$ DNA but did not affect protein content of jejunal sections. Similar to effects observed in the jejunum, GLP-2 tended $(P=0.06)$ to increase ileal total section mass by preferentially increasing $(P$ $=0.04$ ) epithelium mass rather than smooth muscle mass. Ileal DNA and protein content in 0.5-m sections were not affected by treatment. Tissue mass and DNA 
Table 1. The effect of subcutaneous injection of glucagon-like peptide-2 (GLP-2; $100 \mu \mathrm{g} / \mathrm{kg}$ of BW per day) for $10 \mathrm{~d}$ on mean body weight, visceral organ mass, and intestinal length as a percentage of empty body weight of Holstein calves

\begin{tabular}{|c|c|c|c|c|}
\hline Item & Control & GLP-2 & $\mathrm{SEM}^{1}$ & $P$-value \\
\hline Live BW, $\mathrm{kg}$ & 137 & 128 & 8.6 & 0.48 \\
\hline Empty BW, kg & 122 & 115 & 7.5 & 0.55 \\
\hline \multicolumn{5}{|l|}{ Organ, \% empty BW } \\
\hline Gastrointestinal tract & 7.96 & 8.54 & 0.272 & 0.18 \\
\hline Reticulorumen & 2.90 & 2.75 & 0.136 & 0.48 \\
\hline Omasum & 0.69 & 0.75 & 0.040 & 0.30 \\
\hline Abomasum & 0.61 & 0.54 & 0.040 & 0.09 \\
\hline Small intestine & 2.72 & 3.36 & 0.168 & 0.04 \\
\hline Large intestine & 0.89 & 0.94 & 0.065 & 0.44 \\
\hline Liver & 2.29 & 2.13 & 0.085 & 0.23 \\
\hline \multicolumn{5}{|l|}{ Length, m } \\
\hline Small intestine & 30.7 & 29.8 & 1.54 & 0.72 \\
\hline Large intestine & 5.11 & 5.10 & 0.401 & 0.98 \\
\hline \multicolumn{5}{|c|}{ Length:empty BW, cm/kg } \\
\hline Small intestine & 25.6 & 26.0 & 1.50 & 0.86 \\
\hline Large intestine & 4.30 & 4.41 & 0.394 & 0.85 \\
\hline \multicolumn{5}{|l|}{ Mass:length, g/m } \\
\hline Small intestine & 106.9 & 129.4 & 4.22 & 0.02 \\
\hline Large intestine & 211.3 & 213.0 & 15.28 & 0.94 \\
\hline
\end{tabular}

and protein content in $0.5-\mathrm{m}$ colon sections were not affected by treatment.

To evaluate the effect of GLP-2 on intestinal morphology, villus height and crypt depth were measured and the number of BrdU-positive $\left(\mathrm{BrdU}^{+}\right)$cells were counted as an index of crypt cell proliferation (Table 3 and Figure 2). In the duodenum, GLP-2 increased villus height and crypt cell proliferation $(P=0.03$ and $P$ $=0.02$, respectively $)$ and tended $(P=0.06)$ to increase duodenal crypt depth. In the jejunum, GLP-2 tended $(P=0.06)$ to increase villus height and increased crypt depth and crypt cell proliferation $(P=0.02$ and $P=$ 0.01 , respectively). Treatment with GLP-2 tended ( $P$ $=0.09)$ to increase ileal villus height. Although ileal crypt depth was not affected by treatment, crypt cell proliferation in the ileum was increased $(P=0.05)$ with GLP-2. Colon crypt depth and crypt cell proliferation were not affected by treatment.

Table 2. The effect of subcutaneous injection of glucagon-like peptide-2 (GLP-2; $100 \mu \mathrm{g} / \mathrm{kg}$ of BW per day) for $10 \mathrm{~d}$ on mean mass, and DNA and protein content in small intestinal sections $(0.5 \mathrm{~m})$ of Holstein calves

\begin{tabular}{|c|c|c|c|c|}
\hline Intestinal section & Control & GLP-2 & $\mathrm{SEM}^{1}$ & $P$-value \\
\hline \multicolumn{5}{|l|}{ Duodenum } \\
\hline Total section weight, $\mathrm{g}$ & 52.1 & 58.4 & 8.19 & 0.60 \\
\hline Epithelium weight, g & 24.7 & 30.9 & 2.89 & 0.22 \\
\hline Smooth muscle weight, $\mathrm{g}$ & 24.0 & 25.6 & 5.80 & 0.86 \\
\hline DNA, mg & 228 & 282 & 28.6 & 0.10 \\
\hline Protein, mg & 989 & 1,100 & 79.4 & 0.03 \\
\hline \multicolumn{5}{|l|}{ Jejunum } \\
\hline Total section weight, $\mathrm{g}$ & 47.4 & 62.9 & 3.39 & 0.009 \\
\hline Epithelium weight, g & 27.4 & 44.5 & 3.77 & 0.008 \\
\hline Smooth muscle weight, $\mathrm{g}$ & 18.6 & 17.9 & 1.52 & 0.74 \\
\hline DNA, mg & 265 & 412 & 35.3 & 0.01 \\
\hline Protein, $\mathrm{mg}$ & 1,066 & 1,105 & 97.8 & 0.66 \\
\hline \multicolumn{5}{|l|}{ Ileum } \\
\hline Total section weight, $\mathrm{g}$ & 42.8 & 55.6 & 3.92 & 0.06 \\
\hline Epithelium weight, g & 22.7 & 36.4 & 3.65 & 0.04 \\
\hline Smooth muscle weight, $\mathrm{g}$ & 16.4 & 18.0 & 1.52 & 0.49 \\
\hline DNA, mg & 245 & 373 & 52.4 & 0.18 \\
\hline Protein, mg & 1,216 & 1,158 & 105.7 & 0.71 \\
\hline \multicolumn{5}{|l|}{ Colon } \\
\hline Total section weight, $g$ & 102.5 & 78.9 & 15.693 & 0.33 \\
\hline Epithelium weight, g & 15.0 & 24.2 & 4.52 & 0.21 \\
\hline Smooth muscle weight, $\mathrm{g}$ & 46.4 & 37.3 & 6.71 & 0.37 \\
\hline DNA, mg & 123 & 183 & 46.5 & 0.42 \\
\hline Protein, mg & 705 & 710 & 104.7 & 0.97 \\
\hline
\end{tabular}

${ }^{1} \mathrm{n}=4$. 
Table 3. The effect of subcutaneous injection of glucagon-like peptide-2 (GLP-2; $100 \mu \mathrm{g} / \mathrm{kg}$ of BW per day) for $10 \mathrm{~d}$ on mean measures of intestinal morphology and crypt cell proliferation, as indicated by 5-bromo-2'deoxyuridine (BrdU) immunostaining, of Holstein calves

\begin{tabular}{|c|c|c|c|c|}
\hline Intestinal section & Control & GLP-2 & $\mathrm{SEM}^{1}$ & $P$-value \\
\hline \multicolumn{5}{|l|}{ Duodenum } \\
\hline Villus height, $\mu \mathrm{m}$ & 308.1 & 367.0 & 13.650 & 0.03 \\
\hline Crypt depth, $\mu \mathrm{m}$ & 166.7 & 208.6 & 12.452 & 0.06 \\
\hline BrdU $^{+}$cells, $\%$ of total cells & 15.17 & 21.11 & 1.288 & 0.02 \\
\hline \multicolumn{5}{|l|}{ Jejunum } \\
\hline Villus height, $\mu \mathrm{m}$ & 294.4 & 373.1 & 24.098 & 0.06 \\
\hline Crypt depth, $\mu \mathrm{m}$ & 188.2 & 240.1 & 11.824 & 0.02 \\
\hline BrdU $^{+}$cells, $\%$ of total cells & 16.77 & 23.09 & 0.859 & 0.01 \\
\hline \multicolumn{5}{|l|}{ Ileum } \\
\hline Villus height, $\mu \mathrm{m}$ & 227.0 & 270.6 & 15.024 & 0.09 \\
\hline Crypt depth, $\mu \mathrm{m}$ & 167.8 & 161.6 & 8.760 & 0.57 \\
\hline BrdU $^{+}$cells, $\%$ of total cells & 16.90 & 19.99 & 1.602 & 0.05 \\
\hline \multicolumn{5}{|l|}{ Colon } \\
\hline Crypt depth, $\mu \mathrm{m}$ & 317.1 & 329.1 & 20.111 & 0.52 \\
\hline BrdU $^{+}$cells, $\%$ of total cells & 7.74 & 8.14 & 1.124 & 0.71 \\
\hline
\end{tabular}

${ }^{1} \mathrm{n}=4$.

\section{Blood Flow}

Response of SMA blood flow to short-term GLP-2 infusion was dependent on previous exposure to exogenous GLP-2 (Figure 3A and 3B). Analysis of area under the curve for SMA blood flow demonstrated that GLP-2 markedly increased SMA flow in acutely treated calves versus control calves $(2,482.0 \pm 315.5$ vs. 238.1 \pm 122.1 ) but was less effective at increasing SMA flow in chronically treated calves $(968.5 \pm 480.5$ vs. 201.2 \pm 41.7 ; $\mathrm{T} \times \mathrm{D}, P=0.003)$. Likewise, infusion of GLP2 increased SMA blood flow to $175 \%$ of baseline in the acute period but only to $137 \%$ of baseline in the chronic period $(\mathrm{T} \times \mathrm{I}, P=0.0002)$, whereas control infusion did not affect SMA blood flow (Figure 3B). Baseline SMA flow did not differ between acute and chronic exposures $(47.5 \pm 13.1$ and $48.2 \pm 13.8 \mathrm{~L} / \mathrm{h}$ for GLP-2, respectively, vs. $31.2 \pm 4.49$ and $29.8 \pm 3.88$ $\mathrm{L} / \mathrm{h}$ for the control, respectively) although calves in the GLP-2 treatment group tended (T, $P=0.09$ ) to have a slightly higher baseline SMA flow. Based on the consistency of blood flow in control animals and post mortem examination of the probe, the SMA appears to have maintained normal function throughout the experiment. Blood flow of the SMA returned to baseline values during the saline infusion following GLP-2 infusion (Figures 3A and 3B).

\section{DISCUSSION}

\section{Gastrointestinal Organ Mass and Intestinal Morphology}

The importance of GLP-2 in inducing gastrointestinal mucosal growth of the small intestine has been well documented in nonruminant animals (Brubaker et al., 1997). Our current findings extend these previous studies by demonstrating that GLP-2 increases small intestinal growth of the ruminant. As also observed in nonruminants (Tsai et al., 1997a), GLP-2 preferentially increased mass of the small intestine in the ruminant calf without affecting total body mass or mass of other gastrointestinal organs. This growth increase was due to an increase in the mucosal compartment of the small intestine. Increased villus height and BrdU labeling was observed in all 3 segments of the small intestine, whereas increased crypt depth was observed in the duodenum and jejunum and increased mucosal mass was observed in the jejunum and ileum. The localization of mucosal growth observed in this experiment agrees with observations in nonruminants (Drucker et al., 1996; Tsai et al., 1997a; Burrin et al., 2005), and also agrees with the regional localization of GLP-2 receptor mRNA expression in ruminants (Taylor-Edwards et al., 2010) and in nonruminants (Ørskov et al., 2005). In rat, mouse, and man, GLP-2 receptor mRNA is expressed throughout the small intestine, but is most abundant in the proximal small intestine in all 3 species (Ørskov et al., 2005). Thus, despite the substantial differences in diet and foregut anatomy, the small intestinal growth response to GLP-2 in ruminants is similar to that in nonruminants.

Overall, the jejunum showed the most responsiveness to GLP-2 based on increases in all mucosal growth measurements. However, it should be noted that duodenal mucosal mass was $25 \%$ greater for GLP-2-treated calves and both the duodenum and jejunum had a $38 \%$ increase in $\mathrm{BrdU}^{+}$cells with GLP-2 treatment. In addition, GLP-2 increased ileal total and mucosal mass by approximately 30 and $60 \%$, respectively, which is 

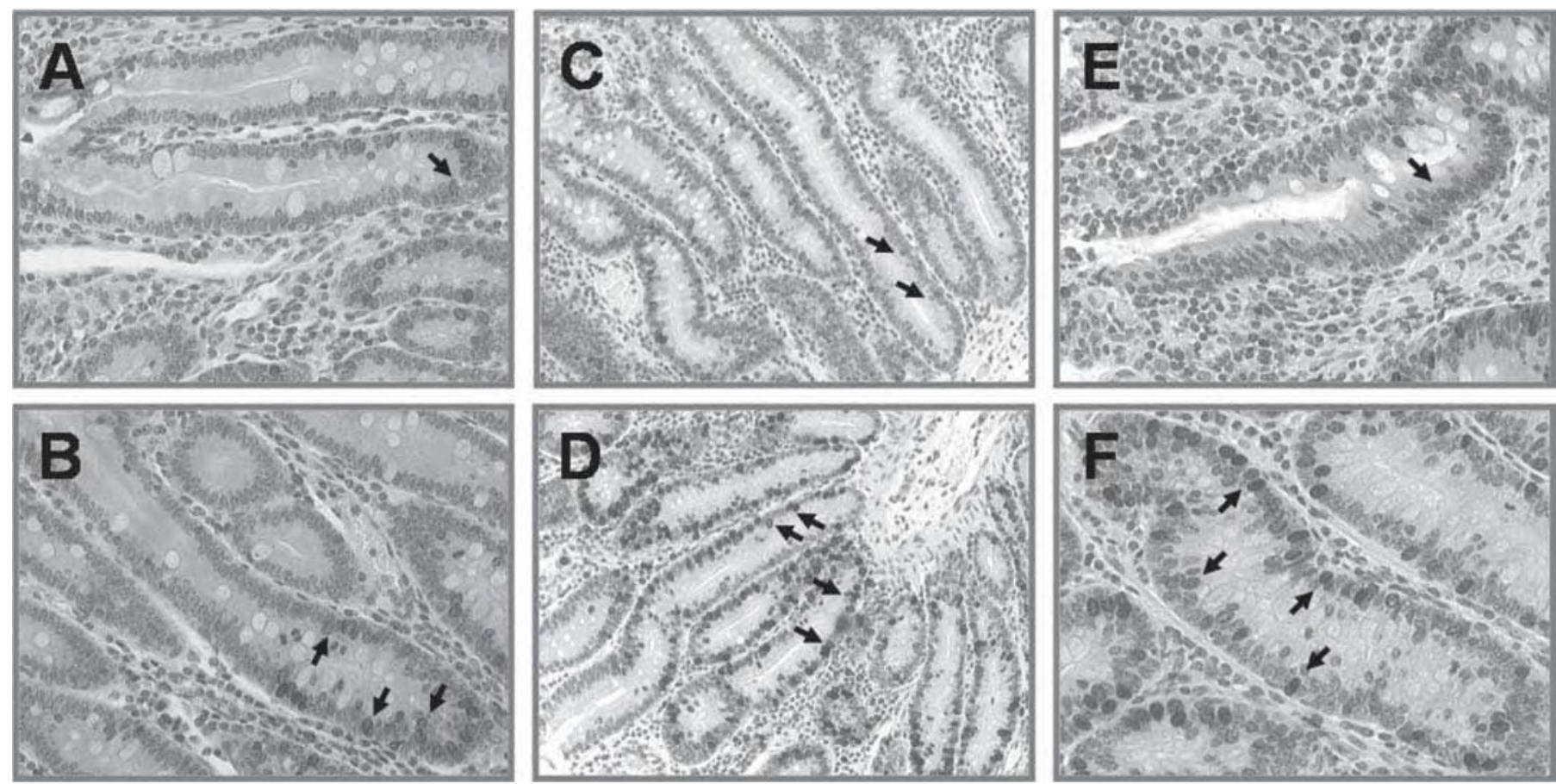

Figure 2. Representative light micrographs of duodenal, jejunal, and ileal tissues stained for 5-bromo-2'-deoxyuridine (BrdU) in calves treated for $10 \mathrm{~d}$ with twice-daily subcutaneous injections of $0.5 \% \mathrm{BSA}$ in saline as control $(\mathrm{n}=4$; A, C, and $\mathrm{E}$, respectively) or $100 \mu \mathrm{g}$ of glucagon-like peptide- $2 / \mathrm{kg}$ of $\mathrm{BW}$ per day $(\mathrm{n}=4 ; \mathrm{B}, \mathrm{D}$, and $\mathrm{F}$, respectively). Images of the duodenum $(\mathrm{A}$ and $\mathrm{B})$ and ileum $(\mathrm{E}$ and $\mathrm{F})$ were obtained at $\times 200$ magnification, and images of the jejunum $(\mathrm{C}$ and $\mathrm{D})$ were obtained at $\times 125$ magnification. Crypt cells staining positively for BrdU are labeled dark brown (black arrows) and are counterstained with hematoxylin.

similar to the 33 and $62 \%$ increases in jejunal total and mucosal mass, respectively. Finally, the $55 \%$ increase $(P=0.01)$ in jejunal DNA content after GLP-2 is paralleled by 52 and $24 \%$ increases in ileal $(P=0.18)$ and duodenal $(P=0.10)$ DNA content, respectively, further indicating hyperplastic growth of all 3 small intestinal segments. The majority of literature reports describe the effects of GLP-2 on measures of jejunal growth. Results from the current experiment agree with others (Tsai et al., 1997a; Burrin et al., 2000; Hartmann et al., 2000b) that jejunal growth is substantially affected by GLP-2, but our results also show that duodenal and ileal mucosal growth is stimulated by GLP-2. Thus, this hormone may have significant benefits for treating animals with compromised intestinal function, such as scouring calves. More broadly, GLP-2 could partially mediate the intestinal adaptation that occurs during significant dietary changes, including those at weaning or at transition to lactation.

\section{SMA Blood Flow}

We also investigated the effects of GLP-2 on SMA blood flow after no or 10-d exposure to exogenous GLP-2. The purpose of this design was to determine if long-term administration (10 d) would attenuate the responsiveness of the gastrointestinal vessels to a short (1-h) continuous infusion of GLP-2. It should be noted that both the short-term infusion and long-term subcutaneous injections were able to achieve pharmacological plasma GLP-2 concentrations (Figure 1). Furthermore, it was notable that the arterial GLP-2 concentrations during the baseline period after $10 \mathrm{~d}$ of GLP-2-treatment (512 pM) were markedly higher than those of the control $(16 \mathrm{pM})$ and reflect the residual peptide in circulation 3 to $7 \mathrm{~h}$ after subcutaneous injection of exogenous GLP-2.

An important finding of this experiment was that a short continuous infusion of GLP-2 increased SMA blood flow to approximately $175 \%$ of baseline flow in acutely treated calves, but only increased flow to approximately $135 \%$ of baseline flow in chronically treated calves that had received GLP-2 for $10 \mathrm{~d}$. However, SMA blood flow during the baseline period (before treatment infusion) did not differ between the 2 treatment groups despite the differences in small intestinal mass that were present on d 10 (Table 1). This demonstrates that GLP-2 did not affect the basal blood flow of the SMA but rather the responsiveness of the SMA to GLP-2 infusion. The increase of SMA blood flow with GLP-2 
A

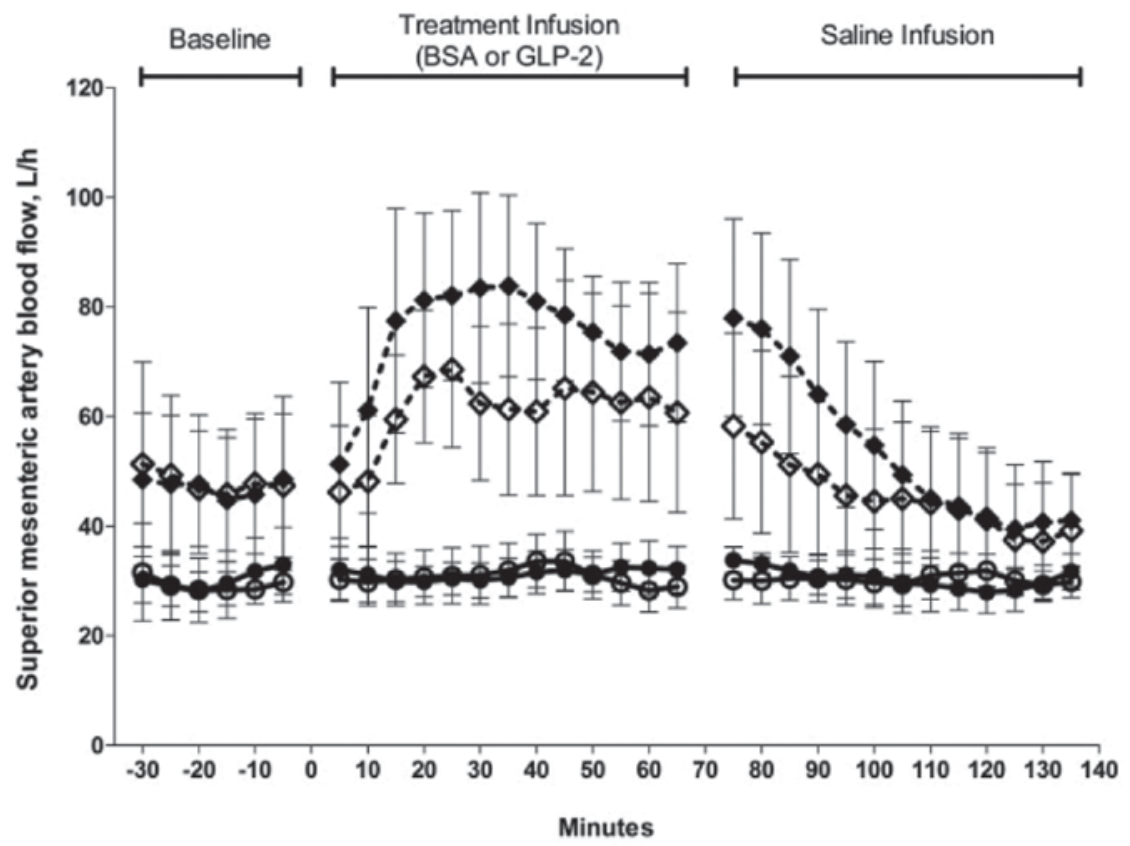

B

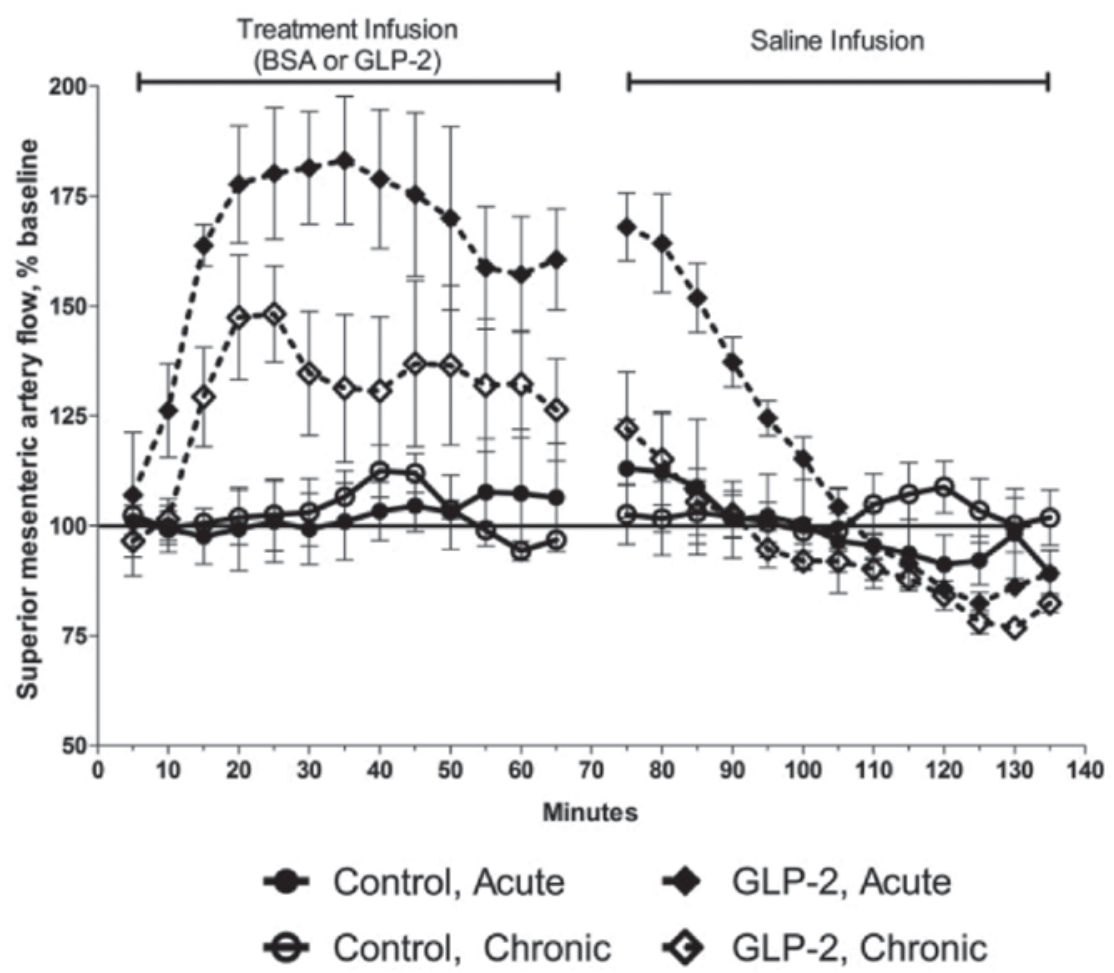

Figure 3. Superior mesenteric artery blood flow shown in L/h (A) and as a percentage of baseline blood flow (B) in calves treated with a control $(\bullet$ or $\bigcirc ; \mathrm{n}=4)$ or GLP-2 $($ or $\diamond ; \mathrm{n}=3)$. Response to intravenous treatment challenge or saline infusion in calves not previously exposed to treatment (acute; closed symbols) or after $10 \mathrm{~d}$ of treatment exposure (chronic; open symbols) was evaluated. Calves in the control group were given the vehicle $(0.5 \%$ BSA in saline) during both the treatment challenge infusion period and as a twice-daily subcutaneous injection for $10 \mathrm{~d}$. Calves in the glucagon-like peptide-2 (GLP-2) treatment group were given 1,000 pmol of GLP-2/kg of BW per hour during the treatment challenge infusion period and $100 \mu \mathrm{g}$ of GLP-2/kg of BW per day as a twice-daily subcutaneous injection for $10 \mathrm{~d}$. Values are expressed as means \pm standard error. 
is consistent with the observations reported in nonruminant models (Guan et al., 2003). However, the blood flow response to GLP-2 has only been documented in response to short-term GLP-2 administration ( $4 \mathrm{~h}$ or less), and the magnitude of the blood flow response to GLP-2 in acutely treated calves is similar to that reported in the literature for pigs (Guan et al., 2003). Our observation that chronic administration of GLP-2 reduced the blood flow response to a short continuous infusion of GLP-2 extends the findings of previous researchers and suggests that in vivo desensitization to exogenous GLP-2 may have occurred in response to chronic GLP-2 administration.

Although desensitization of the GLP-2 receptor has been observed in vitro (Walsh et al., 2003; Estall et al., 2004), no definitive evidence has been observed in vivo. The putative mechanism of GLP-2-mediated stimulation of blood flow is via stimulation of activity and expression of endothelial nitric oxide synthase (Guan et al., 2003, 2006), which increases nitric oxide (NO) production and activates vasodilation of mucosal arterioles (Shah et al., 2004). The generation of NO is not likely the sole effector of GLP-2 on blood flow, because the GLP-2 blood flow response in rats could not be fully abolished with increasing addition of the nonspecific NO synthase inhibitor $\mathrm{N}^{\mathrm{G}}$-nitro-L-arginine methyl ester (Deniz et al., 2007). Additionally, coexpression of the GLP-2 receptor with vasoactive intestinal peptide in enteric neurons and 5-hydroxytryptamine in enteroendocrine cells suggests that these 2 substances may also be involved in the vasodilatory response to GLP-2 (Guan et al., 2006). Whether long-term GLP-2 administration affects its own receptor or responsiveness of secondary messenger generation is unknown, but the current data demonstrate a clear downregulation of the blood flow response to GLP-2 in calves. This finding could have important implications for both the understanding of GLP-2 action and the potential of GLP-2 for long-term clinical applications.

In summary, this experiment demonstrates that ruminants respond to GLP-2 administration in a similar manner to nonruminants. Treatment with GLP-2 increased small intestinal mass by increases in crypt cell proliferation in the small intestine, contributing to increases in villus height, crypt depth, and mucosal mass. Furthermore, we show that GLP-2 infusion increases blood flow of the SMA when administered to calves not previously exposed to exogenous GLP-2. However, we show novel evidence that chronic administration of GLP-2 significantly attenuates this blood flow response. These results extend our understanding of the actions of GLP-2 and may have implications for the use of GLP-2 in treatment of intestinal injury or adaption across species.

\section{ACKNOWLEDGMENTS}

The authors express gratitude to Julie Cannon, Melissa Hudson, Samer El-Kadi, Alma True, Jimmy Klotz, Anne Koontz, and Anne Ballou (University of Kentucky, Lexington, KY) for assistance with tissue collection, to Winston Lin (University of Kentucky) for plasma analysis assistance, and to Xioayan Chang and Leiwei Cui (USDA/ARS Children's Nutrition Research Center, Baylor College of Medicine, Houston, TX) for assistance with immunohistochemistry and morphology measurements. Partial support for this research was provided by the Kentucky Agricultural Experiment Station and is Publication No. 10-07-065. This work was also supported by federal funds from the USDA, Agricultural Research Service under Cooperative Agreement Number 58-6250-6-001 between USDA/ARS Children's Nutrition Research Center, Department of Pediatrics, Baylor College of Medicine and Texas Children's Hospital and by Texas Medical Center Digestive Diseases Center (NIH Grant P30 DK-56338). This manuscript was written by C. C. Taylor-Edwards in her private capacity. No official support or endorsement by the FDA is intended or should be inferred.

\section{REFERENCES}

Bauman, D. E., and W. B. Currie. 1980. Partitioning of nutrients during pregnancy and lactation: A review of mechanisms involving homeostasis and homeorhesis. J. Dairy Sci. 63:1514-1529.

Bremholm, L., M. Hornum, B. M. Henriksen, S. Larsen, and J. J. Holst. 2009. Glucagon-like peptide-2 increases mesenteric blood flow in humans. Scand. J. Gastroenterol. 44:314-319.

Brubaker, P. L., A. Izzo, M. Hill, and D. J. Drucker. 1997. Intestinal function in mice with small bowel growth induced by glucagon-like peptide-2. Am. J. Physiol. 272:E1050-E1058.

Burrin, D. G., B. Stoll, and X. Guan. 2003. Glucagon-like peptide 2 function in domestic animals. Domest. Anim. Endocrinol. 24:103-122.

Burrin, D. G., B. Stoll, X. Guan, L. Cui, X. Chang, and J. J. Holst. 2005. Glucagon-like peptide 2 dose-dependently activates intestinal cell survival and proliferation in neonatal piglets. Endocrinology $146: 22-32$.

Burrin, D. G., B. Stoll, R. Jiang, Y. Petersen, J. Elnif, R. K. Buddington, M. Schmidt, J. J. Holst, B. Hartmann, and P. T. Sangild. 2000. GLP-2 stimulates intestinal growth in premature TPN-fed pigs by suppressing proteolysis and apoptosis. Am. J. Physiol. Gastrointest. Liver Physiol. 279:G1249-G1256.

Deniz, M., A. Bozkurt, and H. Kurtel. 2007. Mediators of glucagonlike peptide 2-induced blood flow: Responses in different vascular sites. Regul. Pept. 142:7-15.

Drucker, D. J., P. Erlich, S. L. Asa, and P. L. Brubaker. 1996. Induction of intestinal epithelial proliferation by glucagon-like peptide 2 . Proc. Natl. Acad. Sci. USA 93:7911-7916.

Estall, J. L., B. Yusta, and D. J. Drucker. 2004. Lipid raft-dependent glucagon-like peptide-2 receptor trafficking occurs independently of agonist-induced desensitization. Mol. Biol. Cell 15:3673-3687.

Guan, X., H. E. Karpen, J. Stephens, J. T. Bukowski, S. Niu, G. Zhang, B. Stoll, M. J. Finegold, J. J. Holst, D. Hadsell, B. L. Nichols, and D. G. Burrin. 2006. GLP-2 receptor localizes to enteric neurons and endocrine cells expressing vasoactive peptides and mediates increased blood flow. Gastroenterology 130:150-164.

Guan, X., B. Stoll, X. Lu, K. A. Tappenden, J. J. Holst, B. Hartmann, and D. G. Burrin. 2003. GLP-2-mediated up-regulation of intes- 
tinal blood flow and glucose uptake is nitric oxide-dependent in TPN-fed piglets 1. Gastroenterology 125:136-147.

Hartmann, B., A. H. Johnsen, C. Ørskov, K. Adelhorst, L. Thim, and J. J. Holst. 2000a. Structure, measurement, and secretion of human glucagon-like peptide-2. Peptides 21:73-80.

Hartmann, B., J. Thulesen, H. Kissow, S. Thulesen, C. Ørskov, C. Ropke, S. S. Poulsen, and J. J. Holst. 2000b. Dipeptidyl peptidase IV inhibition enhances the intestinotrophic effect of glucagon-like peptide-2 in rats and mice. Endocrinology 141:4013-4020.

Huntington, G. B., C. K. Reynolds, and B. H. Stroud. 1989. Techniques for measuring blood flow in splanchnic tissues of cattle. J. Dairy Sci. 72:1583-1595.

Ingvartsen, K. L., and J. B. Andersen. 2000. Integration of metabolism and intake regulation: A review focusing on periparturient animals. J. Dairy Sci. 83:1573-1597.

Johnson, D. E., K. A. Johnson, and R. L. Baldwin. 1990. Changes in liver and gastrointestinal tract energy demands in response to physiological workload in ruminants. J. Nutr. 120:649-655.

Katz, M. L., and E. N. Bergman. 1969. Hepatic and portal metabolism of glucose, free fatty acids, and ketone bodies in the sheep. Am. J. Physiol. 216:953-960.

Labarca, C., and K. Paigen. 1980. A simple, rapid, and sensitive DNA assay procedure. Anal. Biochem. 102:344-352.

Lopez, L. C., M. L. Frazier, C. J. Su, A. Kumar, and G. F. Saunders. 1983. Mammalian pancreatic preproglucagon contains three glucagon-related peptides. Proc. Natl. Acad. Sci. USA 80:5485-5489.

Massimino, S. P., M. I. McBurney, C. J. Field, A. B. Thomson, M. Keelan, M. G. Hayek, and G. D. Sunvold. 1998. Fermentable dietary fiber increases GLP-1 secretion and improves glucose homeostasis despite increased intestinal glucose transport capacity in healthy dogs. J. Nutr. 128:1786-1793.

McLeod, K. R., and R. L. Baldwin. 2000. Effects of diet forage:concentrate ratio and metabolizable energy intake on visceral organ growth and in vitro oxidative capacity of gut tissues in sheep. J. Anim. Sci. 78:760-770.

McLeod, K. R., M. L. Bauer, D. L. Harmon, C. K. Reynolds, and G. E. Mitchell Jr.. 1997. Effects of exogenous somatostatin and cysteamine on net nutrient flux across the portal-drained viscera and liver of sheep during intraduodenal infusion of starch hydrolysate and casein. J. Anim. Sci. 75:3026-3037.

National Research Council. 2001. Nutrient Requirements of Dairy Cattle. 7th rev. ed. National Academy Press, Washington, DC.

Ørskov, C., B. Hartmann, S. S. Poulsen, J. Thulesen, K. J. Hare, and J. J. Holst. 2005. GLP-2 stimulates colonic growth via KGF, released by subepithelial myofibroblasts with GLP-2 receptors. Regul. Pept. 124:105-112.

Ørskov, C., and J. J. Holst. 1987. Radio-immunoassays for glucagonlike peptides 1 and 2 (GLP-1 and GLP-2). Scand. J. Clin. Lab. Invest. $47: 165-174$.

Ørskov, C., J. J. Holst, S. Knuhtsen, F. G. A. Baldissera, S. S. Poulsen, and O. V. Nielsen. 1986. Glucagon-like peptides GLP-1 and GLP-2, predicted products of the glucagon gene, are secreted separately from pig small intestine but not pancreas. Endocrinology 119:1467-1475.

Raben, A., L. Agerholm-Larsen, A. Flint, J. J. Holst, and A. Astrup. 2003. Meals with similar energy densities but rich in protein, fat, carbohydrate, or alcohol have different effects on energy expenditure and substrate metabolism but not on appetite and energy intake. Am. J. Clin. Nutr. 77:91-100.

Ramsanahie, A. P., U. V. Berger, M. J. Zinner, E. E. Whang, D. B. Rhoads, and S. W. Ashley. 2004. Effect of glucagon-like peptide-2 (GLP-2) on diurnal SGLT1 expression. Dig. Dis. Sci. 49:17311737 .

Relling, A. E., and C. K. Reynolds. 2007a. Feeding rumen-inert fats differing in their degree of saturation decreases intake and increases plasma concentrations of gut peptides in lactating dairy cows. J. Dairy Sci. 90:1506-1515.

Relling, A. E., and C. K. Reynolds. 2007b. Plasma concentrations of gut peptides in dairy cattle increase after calving. J. Dairy Sci. 90:325-330

Relling, A. E., and C. K. Reynolds. 2008. Abomasal infusion of casein, starch and soybean oil differentially affect plasma concentrations of gut peptides and feed intake in lactating dairy cows. Domest. Anim. Endocrinol. 35:35-45.

Reynolds, C. K., B. Durst, B. Lupoli, D. J. Humphries, and D. E. Beever. 2004. Visceral tissue mass and rumen volume in dairy cows during the transition from late gestation to early lactation. J. Dairy Sci. 87:961-971.

Shah, V., G. Lyford, G. Gores, and G. Farrugia. 2004. Nitric oxide in gastrointestinal health and disease. Gastroenterology 126:903913.

Stephens, J., B. Stoll, J. Cottrell, X. Chang, M. Helmrath, and D. G. Burrin. 2006. Glucagon-like peptide-2 acutely increases proximal small intestinal blood flow in TPN-fed neonatal piglets. Am. J. Physiol. Regul. Integr. Comp. Physiol. 290:R283-R289.

Suominen, A. H., D. R. Glimm, D. Tedesco, E. K. Okine, M. I. McBurney, and J. J. Kennelly. 1998. Intestinal nutrient-gene interaction: The effect of feed deprivation and refeeding on cholecystokinin and proglucagon gene expression. J. Anim. Sci. 76:3104-3113.

Taylor-Edwards, C. C., D. G. Burrin, J. C. Matthews, K. R. McLeod, J. J. Holst, and D. L. Harmon. 2010. Expression of proglucagon and glucagon-like peptide-2 (GLP-2) receptor mRNA in the ruminant gastrointestinal tract and the influence of energy intake. Domest. Anim. Endocrinol. 39:181-193.

Tsai, C. H., M. Hill, S. L. Asa, P. L. Brubaker, and D. J. Drucker. 1997a. Intestinal growth-promoting properties of glucagon-like peptide-2 in mice. Am. J. Physiol. 273:E77-E84.

Tsai, C. H., M. Hill, and D. J. Drucker. 1997b. Biological determinants of intestinotrophic properties of GLP-2 in vivo. Am. J. Physiol. 272:G662-G668.

Walsh, N. A., B. Yusta, M. P. DaCambra, Y. Anini, D. J. Drucker, and P. L. Brubaker. 2003. Glucagon-like peptide-2 receptor activation in the rat intestinal mucosa. Endocrinology 144:4385-4392.

Wojdemann, M., A. Wettergren, B. Hartmann, and J. J. Holst. 1998 Glucagon-like peptide-2 inhibits centrally induced antral motility in pigs. Scand. J. Gastroenterol. 33:828-832.

Xiao, Q., R. P. Boushey, D. J. Drucker, and P. L. Brubaker. 1999 Secretion of the intestinotropic hormone glucagon-like peptide 2 is differentially regulated by nutrients in humans. Gastroenterology 117:99-105. 